\title{
Исходный материал для создания сортов овса универсального использования
}

Пай О.А. ${ }^{1,2 *}$, Фомина М.Н. ${ }^{1,2}$, Иванова Ю.С., ${ }^{1,2}$

${ }^{1}$ Государственный аграрный университет Северного Зауралья, Тюмень, Россия

${ }^{2}$ Научно-исследовательский институт сельского хозяйства Северного Зауралья филиал Федерального исследовательского ичентра ТюмНЦ СО РАН, пос. Московский, Тюменская область, Россия

*e-mail: ola92ola@mail.ru

В условиях Северного Зауралья в 2016-2018 гг. была проведена комплексная оценка 80 коллекционных образцов (из коллекции ФГБНУ Федеральный исследовательский центр «Всероссийский институт генетических ресурсов растений им. Н.И. Вавилова») и 22 селекционных номеров, созданных в НИИСХ Северного Зауралья. Результаты изучения показали достаточно высокую изменчивость по урожайности зерна, зеленой массы и сбору сухого вещества. Свыше 30 \% изученных образцов формировали высокий урожай зерна, но уступали стандарту (Талисман) по урожаю зеленой массы и сбору сухого вещества. Большая часть образцов (52 \%) превосходила стандарт (Талисман) по урожаю зеленой массы и сбору сухого вещества, но уступала ему по урожаю зерна. Перспективный исходный материал для создания сортов овса универсального использования (на зерно и зеленый корм) составил 16 \%. Большой интерес в этом плане представляют номера: К-14376, Avalanche, (Франция); К-15279, 50h2035 (Московская область), ТМ 08-123-5, ТМ 04-22-2, ТМ 07-84-8, ТМ 08-140-2, Тоболяк (Тюменская область). Выделенные образцы формировали урожай зерна от 544.3 до 615.9 г/м² (при урожае стандартного сорта Талисман 524.5 г/ $\mathrm{m}^{2}$ ). Сбор сухого вещества у них варьировал

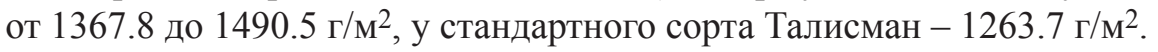

